\title{
FALL 1984
}

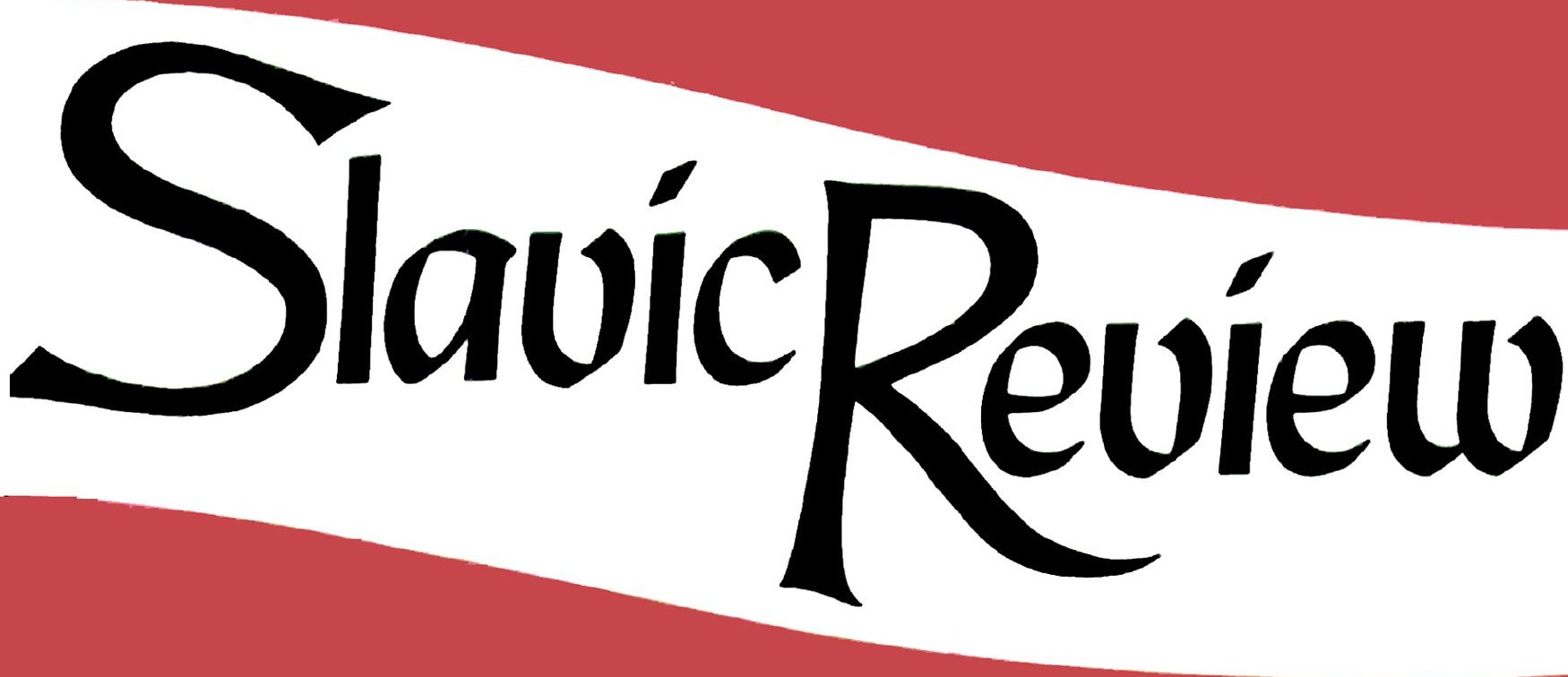

\section{AMERICAN QUARTERLY OF SOVIET AND EAST EUROPEAN STUDIES}

Richard Gregg : The Cooling of Pechorin: The Skull Beneath the Skin

Alan Ball : Lenin and the Question of Private Trade in Soviet Russia

Robert E. Jones : Getting the Goods to St. Petersburg:

Water Transport from the Interior 1703-1811

J. H. Seddon : The Petrashevtsy: A Reappraisal

Toivo U. Raun : The Revolution of 1905 in the Baltic Provinces and Finland 


\section{EDITOR}

David L. RANSEL

ASSOCIATE EDITOR

ASSISTANT EDITOR

STAFF ASSISTANT
GITTA BRIDgES

Mary E. Theis

Melisa A. Seider

HONORARY EDITORS: Frederick Barghoorn • Vera S. Dunham • John N. Hazard • Gleb Struve - Marc M. Szeftel • René Wellek

EDITORIAL BOARD: Jan S. Adams, Ohio State University • George W. Breslauer, University of California - Malcolm Hamrick Brown, Indiana University $•$ Patricia Carden, Cornell University - Paul R. Gregory, University of Houston - Keith Hitchins, University of Illinois at UrbanaChampaign - James Michael Holquist, Indiana University - Ann M. Kleimola, University of Nebraska - Bernice Madison, San Francisco State College - Robert A. Maguire, Columbia University • Walter M. Pintner, Cornell University • James P. Scanlan, Ohio State University • H. Gordon Skilling, University of Toronto - Victor Terras, Brown University - Alexander Vucinich, University of Pennsylvania • Piotr S. Wandycz, Yale University - Richard Wortman, Princeton University

CONSULTANTS ON SOVIET AND EAST EUROPEAN BOOKS: George Barany, University of Denver - John D. Bell, University of Maryland Baltimore County - Imre Boba, University of Washington - Wesley A. Fisher, Columbia University - Keith Hitchins, University of Illinois at Urbana-Champaign - Charles Jelavich, Indiana University • John E. Malmstad, Columbia University • Daniel Orlovsky, Southern Methodist University

The editors assume no responsibility for statements of fact or opinion made by contributors.

The Slavic Review (ISSN 0037-6779) (formerly The American Slavic and East European Review) is published quarterly by the American Association for the Advancement of Slavic Studies, Inc., and is sent to all Association members. Members also receive the AAASS Newsletter. Membership is open to individuals interested in the advancement of Slavic studies (including study of the non-Slavic peoples of Eastern Europe and the USSR), and applications for membership are accepted by the Executive Director, Dorothy Atkinson, 128 Encina Commons, Stanford University, Stanford, CA 94305 . Membership dues: salary $\$ 10,000$ to $\$ 19,999-$ $\$ 30.00 ; \$ 20,000$ to $\$ 29,999-\$ 35.00 ; \$ 30,000$ to $\$ 39,000-\$ 40.00 ; \$ 40,000$ to $\$ 49,999-\$ 45.00$; over $\$ 50,000-\$ 50.00$. Joint members with one subscription to the Slavic Review, add $\$ 10.00$ to dues of higher paid member. Dues for students, emeriti, or those with salaries under $\$ 10,000$ are $\$ 15.00$. New Affiliate (Newsletter only): $\$ 15.00$. Subscriptions without membership are $\$ 45.00$. Single current issues and back issues to subscribers are $\$ 15.00$; back issues for members are $\$ 10.00$ each. Correspondence regarding membership, subscriptions, changes of address, or items for the Newsletter should be sent to the AAASS headquarters in Stanford.

Articles, books for review, and correspondence concerning advertising and editorial matters should be sent to Slavic Review, University of Illinois at Urbana-Champaign, 911 West High Street, Room 200, Urbana, Illinois 61801. Technical requirements for manuscript submissions are given on the inside back cover.

Published by the American Association for the Advancement of Slavic Studies, Inc. Composition by Brevis Press, Bethany, Connecticut. Printed by Heffernan Press, Inc., Worcester, Massachusetts. Second-class postage paid at Palo Alto, CA and additional mailing office. POSTMASTER: Send address changes to Slavic Review, c/o AAASS, 128 Encina Commons, Stanford University, Stanford, CA 94305.

Copyright $\mathbb{C} 1984$ by the American Association for the Advancement of Slavic Studies, Inc. 


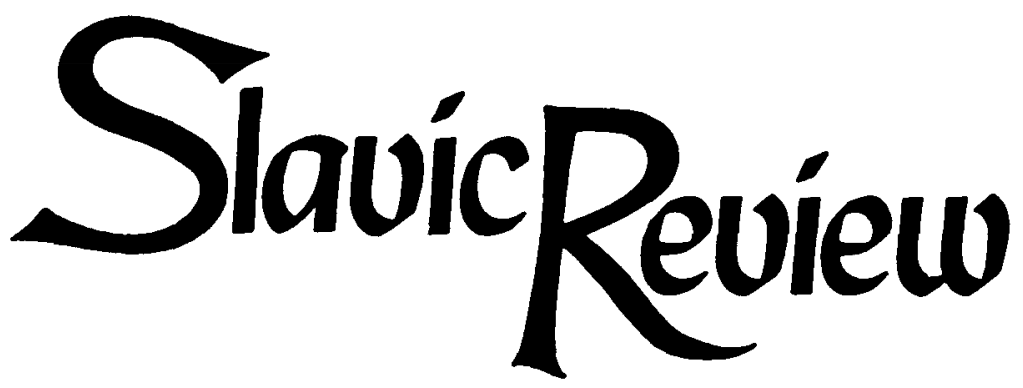

AMERICAN QUARTERLY OF SOVIET AND

EAST EUROPEAN STUDIES

EDITOR

DAVID L. RANSEL

University of Illinois at Urbana-Champaign

Volume $43 \cdot 1984$

Copyright (C) 1984 by the American Association for the Advancement of Slavic Studies, Inc. 


\section{CONTENTS OF VOLUME 43}

\section{Number 1, Spring 1984}

\section{ARTICLES}

David M. Bethea: 1944-1953: Ivan Bunin and the

Time of Troubles in Russian Émigré Literature

Bronislava Volek: The Guinea Pigs by Ludvík

Vaculík: Codes, Metaphors, and Compositional

Devices

David S. Mason: The Polish Party in Crisis, 19801982

Lawrence N. Langer: The Posadnichestvo of Pskov:

Some Aspects of Urban Administration in

Medieval Russia

E. Willis Brooks: Reform in the Russian Army, 18561861

\section{NOTES AND COMMENT}

Steven Rosefielde: Excess Collectivization Deaths 1929-1933: New Demographic Evidence

\section{REVIEW ESSAY}

Alfred Erich Senn: Two Lives in the Three Rings of Soviet Popular Culture

REVIEWS

NEWS OF THE PROFESSION

BOOKS RECEIVED

SYMPOSIA

\section{Number 2, Summer 1984}

\section{ARTICLES}

R. W. Davies: The Socialist Market: A Debate in Soviet Industry, 1932-33

Laura D. Weeks: Hebraic Antecedents in The Master and Margarita: Woland and Company Revisited

Judith Pallot: Khutora and Otruba in Stolypin's

Program of Farm Individualization

Robert M. Croskey: The Diplomatic Forms of Ivan III's Relationship with the Crimean Khan 


\section{NOTES AND COMMENT}

Hugh Ragsdale: The Microfilmed Collections of

Russian Archival Materials in the Danish and

Swedish National Archives

Miranda Beaven: Readership in Early Nineteenth-

Century Russia: Recent Soviet Research

Richard Tempest: Madman or Criminal: Government Attitudes to Petr Chaadaev in 1836

REVIEW ESSAY

Richard Sheldon: The Legacy of Mikhail Sholokhov, 1905-1984

REVIEWS

291

LETTERS

NEWS OF THE PROFESSION

BOOKS RECEIVED

SYMPOSIA

\section{Number 3, Fall 1984}

\section{ARTICLES}

Richard Gregg: The Cooling of Pechorin: The Skull Beneath the Skin

Alan Ball: Lenin and the Question of Private Trade in Soviet Russia

Robert E. Jones: Getting the Goods to St. Petersburg: Water Transport from the Interior 1703-1811

J. H. Seddon: The Petrashevtsy: A Reappraisal

Toivo U. Raun: The Revolution of 1905 in the Baltic Provinces and Finland

REVIEWS

REFERENCE BOOKS OF 1982-83: A SELECTION

LETTERS

$\begin{array}{lr}\text { NEWS OF THE PROFESSION } & 550\end{array}$

BOOKS RECEIVED $\quad 552$

$\begin{array}{ll}\text { SYMPOSIA } & 559\end{array}$ 


\section{Number 4, Winter 1984}

ARTICLES

Katerina Clark: The Mutability of the Canon:

Socialist Realism and Chingiz Aitmatov's

I dol'she veka dlitsia den'

Ellen Chances: Aleksandr Miliukov's Svetoch and

Dostoevskii's Vremia: A Case of Recycled Ideas?

588

John P. McKay: Baku Oil and Transcaucasian

Pipelines, 1883-1891: A Study in Tsarist

Economic Policy

604

Laszlo Deme: Writers and Essayists and the Rise of

Magyar Nationalism in the 1820 s and 1830 s

624

Ellen Mickiewicz: The Functions of Communications

Officials in the USSR: A Biographical Study

641

\section{NOTES AND COMMENT}

John Thomas Sanders: "Once More Into the Breach,

Dear Friends": A Closer Look at Indirect Tax

Receipts and the Condition of the Russian

Peasantry, 1881-1899

$\begin{array}{ll}\text { James Y. Simms: Reply } & 667\end{array}$

$\begin{array}{lr}\text { REVIEWS } & 672\end{array}$

$\begin{array}{ll}\text { LETTERS } & 751\end{array}$

$\begin{array}{ll}\text { NEWS OF THE PROFESSION } & 753\end{array}$

$\begin{array}{ll}\text { DOCTORAL DISSERTATIONS, 1983-1984 } & 754\end{array}$

(Compiled by Jesse J. Dossick)

$\begin{array}{ll}\text { BOOKS RECEIVED } & 763\end{array}$

$\begin{array}{ll}\text { SYMPOSIA } & 770\end{array}$

INDEX TO VOLUME 43 (1984) 772 